\title{
MAKNA AL-MUTAKABBIR DALAM ALQURAN (STUDI KAJIAN SEMANTIK)
}

\author{
Nuri Meilan, Kholid Al-Walid, Solehudin \\ Fakultas Ushuluddin UIN Sunan Gunung Djati Bandung \\ J1.A.H.Nasution 105 Cibiru Bandung 40614, Indonesia \\ E-Mail : $\underline{\text { rifa.roifa@yahoo.com }}$
}

\begin{abstract}
Abstrak
Takhallaqū bi akhlākillāh 'berakhlaklah kamu seperti akhlaq Allah', jika Hadith tersebut mesti dijadikan acuan

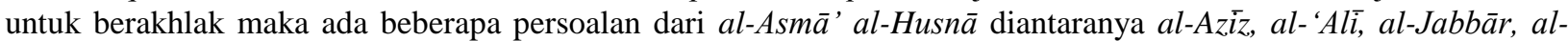
Qahhār, al-Mutakabbir, dll. Sifat-sifat ini walaupun namanya sama dengan yang dinisbatkan pada manusia, namun mempunyai hakikat yang berbeda. Salah satunya adalah al-Mutakabbir (Yang memiliki segala keagungan). Jika merujuk kepada Hadith di atas tentu bertentangan dengan ayat Alquran dan Hadith yang jelas mengatakan bahwa manusia dilarang bersikap sombong dan balasan yang berbuat sombong adalah neraka. Penelitian ini membahas makna lafal al-Mutakabbir melalui pendekatan Semantik, jenis penelitian kualitatif, dengan menggunakan teknik pengumpulan data library research (penelitian kepustakaan). Metode yang digunakan adalah deskriptif analysis yaitu menganalisis memaparkan dan menganalisis lafal al-Mutakabbir dalam Alquran. Hasil dari penelitian ini ialah lafal al-Mutakabbir berasal dari kata kabura mempunyai makna besar. Sedangkan jika dilihat dari kamus-kamus bahasa Arab kata kabura artinya mengagungkan, sombong, menjadi besar, membesarkan, lawan dari kata shagura (kecil), pembesar (pemimpim), sesuatu yang lebih tua atau lebih utama. Kata al-Mutakabbir ini selalu dikaitkan dengan dua subjek/ pelaku berbeda. Subjek yang ditujukkan kepada Allah Swt., memiliki tendensi makna positif, sama dengan al-Asmā' al-Husnā. Subjek kedua ditujukan kepada manusia yang memiliki makna negatif.
\end{abstract}

\section{Kata Kunci :}

al-Mutakabbir; semantik; al-Asmā' al-Husnā.

\begin{abstract}
Takhallaqū bi akhlākillāh 'morals you as the morality of God', if the Hadith showed as a reference for morality then there are some problems of al-Asmā 'al-Husnā such as al-Azī z, al-'AГī, al-Jabbār, al- Qahhār, al-Mutakabbir, etc. These qualities despite their names are the same as those attributed to humans but have a different nature. One of them is al-Mutakabbir (who has all the majesty). If it refers to the Hadith above it would be contrary to Quranic verses and Hadith which says that people are forbidden to be arrogant, and the recompense that is arrogant is hell. This study discusses the meaning of pronunciation al-Mutakabbir through semantic approach, the type of qualitative research, using data collection techniques library research (library research). The method used is the descriptive analysis that is analyzing explaining and analyzing the al-Mutakabbir pronunciation in Alquran. The result of this research is the pronunciation of al-Mutakabbir derived from the word kabura has a big meaning. Meanwhile, when viewed from the dictionaries of the Arabic word kabura means to glamorize, arrogant, to be great, to raise, the opposite of the word shagura (small), magnifying (leader), something older or more mainstream. The word al-Mutakabbir is always associated with two different subjects/actors. The subject that is addressed to Allah SWT has a positive meaning, similar to al-Asmā 'al-Husnā. The second subject is addressed to humans who have a negative meaning.
\end{abstract}

Keywords:

al-Mutakabbir; semantik; al-Asmä' al-Husnā.

\section{A. PENDAHULUAN}

Allah menyifati diri-Nya dalam Alquran, tidak ada seorangpun dari sahabat Nabi Saw, yang bertanya kepadanya mengenai arti sifat- sifat itu, sebagaimana mereka bertanya kepadanya mengenai salat, zakat, puasa dan lainnya yang berkaitan dengan perintah dan 
larangan, atau sebagaimana mereka bertanya mengenai kiamat, surga dan neraka. ${ }^{1}$

Padahal ketika sifat-sifat baik dan terpuji yang disandang manusia/ makhluk, seperti hidup, kuasa, pengetahuan, pendengaran, penglihatan, kemuliaan, kasih sayang dan sebagainya, maka pastilah yang Maha Kuasapun memiliki sifat-sifat baik dan terpuji dalam kapasitas dan substansi yang lebih sempurna. $^{2}$ Jika tidak demikian, apa arti kebutuhan manusia kepada-Nya?. Nama atau sifat-sifat yang disandang-Nya itu, terambil dari bahasa manusia, namun kata yang digunakan saat di sandang manusia, pasti selalu mengandung makna kebutuhan serta kekurangan, walaupun ada di antaranya yang tidak dapat dipisahkan dari kekurangan tersebut dan ada pula yang dapat dipisahkan. ${ }^{3}$

Bagaimana sifat yang disandangkan kepada Allah, yang oleh kebanyakan manusia, sangat buruk dan jelek, yaitu sifat alMutakabbir. Lafal tersebut terambil dari akar kata yang mengandung makna kebesaran serta lawan dari kemudahan atau kekecilan. Mutakabbir biasa diterjemahkan dengan "angkuh". 4 Sifat takabbur atau sombong yang melekat kepada diri manusia menunjukkan keangkuhan karena mempunyai kemampuan, ekonomi ataupun kekuasaan. Dan sifat ini merupakan penyakit yang ada dalam diri manusia, psikolog biasa menyebutnya dengan

${ }^{1}$ A.Hidayat, Teologi Qur'āni, (Bandung: Gunung Djati Press, 1998),8.

${ }^{2}$ Dia sama sekali berbeda dengan makhluk-Nya dalam segi sifat-sifat-Nya. Didalam Dzat-Nya tidak ada unsur lain, sementara pada yang lain juga tidak ada Dzat-Nya. Dia suci dari segala perubahan dan pergantian, tidak ditempati oleh segala yang bersifat baru (hawādits) dan tidak dihinggapi oleh sifat-sifat baru yang non-esensial, akan tetapi Dia senantiasa dalam sifat-sifat keagungan-Nya yang tersucikan dari sifat aus/ fana dan sirna dalam sifat-sifat kesempurnaanNya itu tidak memerlukan penyempurnaan tambahan. Abu Hamid al-Ghazali, Tauhidullah: Risalah Suci Hujjatul Islam, Cet. III ,(Surabaya: Tp, 2001), 5.

${ }^{3}$ Baca pendahuluan Quraish Shihab, Menyingkap Tabir Ilahi (Asmā' al-Husnā dalam perspektif alQur'ān), (Jakarta: Lentera Hati, 2003), 1.

${ }^{4}$ Quraish Shihab,Menyingkap Tabir Ilahi, 70.
"Megalomania"5, yaitu penyakit yang menganggap dirinya besar.

Oleh sebab itu, penulis berusaha meneliti kata al-Mutakabbir yang disifatkan kepada Allah dengan metode semantik Alquran Izutsu, mengetahui konsep dari al-Mutakabbir dalam Alquran.

\section{B. PEMBAHASAN \\ 1. Makna Dasar}

Al-Mutakabbir adalah lafal yang berarti keagungan atau kemahabesaran Allah SWT, dan merupakan bagian dari Asmā' al-Husnā. Kata al-Mutakabbir terbentuk dari wazan takabbara-yatakabbaru, dan asal katanya adalah kabura. Kata kabira-yakbaru memiliki pola seperti ta'iba isim fā'il kabïrun jama'nya kibārun, isim fā'il kabira untuk jenis perempuan kabiratun, pola superlatif (isim tafọi) kata kabïrun yaitu akbarun/ al-akbaru yang bentuk pluralnya (jama') akābir, dan bentuk plural kabïratun adalah kubrā/ alkubrā, jama'nya kubarun dan kubrayāt. Kata kabiratun diartikan dengan al-itsmu (dosa), jama'nya akābir, terkadang bentuk jama'nya kabïrātu. Pola kata kabura memiliki pola yang sama dengan qaruba dimaknai dengan sinonim 'azhuma adalah sama dengan kabirun, pola kata kubira maknanya mu'zhamun (mayoritasnya). Pola kata kibrun merupakan nama yang diartikan dengan takabbur. Ibnu Qautiyah berkata kata al-kibru memiliki makna besarnya sesuatu/ besarnya dosa, kata dasarnya adalah kibran, yang memiliki konotasi makna al-kibriyā'. Terkadang pula kata akbar dimaknai dengan kata kabïr, misalnya pernyataan al-akbār dan al-aşghar itu bisa berarti al-Kabir/al-shaghir.

Adapun bentuk kata al-Mutakabbir dengan berbagai derivasinya terulang 57 kali. $^{6}$

5 J.P. Chaplin, Kamus Lengkap Psikologi, Terj. Kartini Kartono. (Jakarta: PT Raja Grafindo Persada, 2011), V.

${ }^{6}$ Muhammad Fu'ad 'Abdul Bāqî, Al-Mu'jam AlMufahras Li Alfādz Al-Qur'ān Al-Karîm, (Kairo: Dar Al-Hadits, 2007), 588-591. 


\begin{tabular}{|c|c|c|c|c|}
\hline $\begin{array}{l}\mathbf{N} \\
\mathbf{0}\end{array}$ & $\begin{array}{c}\text { Bentuk } \\
\text { Kata }\end{array}$ & $\begin{array}{l}\text { Nama } \\
\text { Surat }\end{array}$ & $\begin{array}{c}\text { Nomor } \\
\text { Ayat }\end{array}$ & Makna \\
\hline 1 & كَبرَ & $\begin{array}{c}\text { Al- } \\
\text { An'ām }\end{array}$ & 35 & amat berat \\
\hline 2 & كَبْرَ & $\begin{array}{c}\text { Al- } \\
\text { Mu'min }\end{array}$ & 35 & $\begin{array}{c}\text { Amat besar } \\
\text { kemurkaan } \\
\text { (bagi } \\
\text { mereka) }\end{array}$ \\
\hline 3 & كَبْرَ & $\begin{array}{l}\text { Ash- } \\
\text { Shaff }\end{array}$ & 3 & $\begin{array}{c}\text { Amat besar } \\
\text { kebencian }\end{array}$ \\
\hline 4 & كَبرَتَتْ & Al-Kaḩfi & 5 & $\begin{array}{l}\text { Alangkah } \\
\text { buruknya }\end{array}$ \\
\hline 5 & يَكَبُرُ & Al-Isrā' & 51 & $\begin{array}{l}\text { Alangkah } \\
\text { buruknya }\end{array}$ \\
\hline 6 & يَكِبَرُوْا & Al-Nisā' & 6 & $\begin{array}{c}\text { sebelum } \\
\text { mereka } \\
\text { dewasa }\end{array}$ \\
\hline 7 & 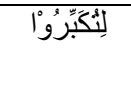 & $\begin{array}{c}\text { Al- } \\
\text { Baqarah }\end{array}$ & 185 & $\begin{array}{l}\text { mengagun } \\
\text { gkan Allah }\end{array}$ \\
\hline 8 & فَكَبِّر & $\begin{array}{c}\text { Al- } \\
\text { Muddatst } \\
\text { sir }\end{array}$ & 3 & $\begin{array}{c}\text { agungkanl } \\
\text { ah }\end{array}$ \\
\hline 9 & كبرَّرْْْ & Al-Isrā' & 111 & $\begin{array}{c}\text { agungkanl } \\
\text { ah Dia } \\
\text { (Allah) }\end{array}$ \\
\hline 10 & أَبَبرَنْنَهُ & Yūsuf & 31 & $\begin{array}{c}\text { mereka } \\
\text { kagum } \\
\text { kepada nya }\end{array}$ \\
\hline 11 & كََكَبَّرَ & Al-A'rāf & 13 & $\begin{array}{l}\text { menyombo } \\
\text { ngkan diri }\end{array}$ \\
\hline 12 & يَتَكَبََرُوْنَ & Al-A'rāf & 146 & $\begin{array}{c}\text { menyombo } \\
\text { ngkan } \\
\text { dirinya }\end{array}$ \\
\hline 13 & اسْتَكَبرَ & $\begin{array}{c}\text { Al- } \\
\text { Baqarah }\end{array}$ & 34 & takabur \\
\hline 14 & اسْنَكبَرَ & $\begin{array}{c}\text { Al- } \\
\text { Qashash }\end{array}$ & 39 & angkuhlah \\
\hline 15 & اسْنَخَبَرَ & Shād & 74 & $\begin{array}{l}\text { menyombo } \\
\text { ngkan diri }\end{array}$ \\
\hline 16 & اسْنَكَبَرْتَتَ & $\begin{array}{c}\text { Al- } \\
\text { Zumar }\end{array}$ & 59 & $\begin{array}{l}\text { menyombo } \\
\text { ngkan diri }\end{array}$ \\
\hline 17 & اسنتخبَبرَنْْْ & $\begin{array}{c}\text { Al- } \\
\text { Baqarah }\end{array}$ & 87 & $\begin{array}{c}\text { kamu } \\
\text { menyombo } \\
n g\end{array}$ \\
\hline 18 & اسنْكَبَرُوْوا & Al-Nisā' & 173 & menyombo \\
\hline
\end{tabular}

\begin{tabular}{|c|c|c|c|c|}
\hline & & & & ngkan diri \\
\hline 19 & اسْنَكَبَرُوْْا & Ibrāhim & 21 & $\begin{array}{c}\text { orang- } \\
\text { orang yang } \\
\text { sombong }\end{array}$ \\
\hline 20 & اسْنَكْبَرُوْْا & $\begin{array}{c}\text { Al- } \\
\text { Mu'minū } \\
\mathrm{n}\end{array}$ & 46 & $\begin{array}{c}\text { mereka ini } \\
\text { takabur }\end{array}$ \\
\hline 21 & اسْنَكْبَرُوْْا & $\begin{array}{c}\text { Al- } \\
\text { Furqān }\end{array}$ & 21 & $\begin{array}{c}\text { memandan } \\
\text { g besar } \\
\text { tentang } \\
\text { diri } \\
\text { mereka }\end{array}$ \\
\hline 22 & تَسْنَكَبْرُوْنَ & $\begin{array}{c}\text { Al- } \\
\text { An'ām }\end{array}$ & 93 & $\begin{array}{l}\text { menyombo } \\
\text { ngkan diri }\end{array}$ \\
\hline 23 & يَسْنَكَبرَ & Al-Nisā' & 172 & $\begin{array}{l}\text { menyombo } \\
\text { ngkan diri }\end{array}$ \\
\hline 24 & يَسْنَكَبْرُوْنَ & $\begin{array}{c}\text { Al- } \\
\text { Maidah }\end{array}$ & 82 & $\begin{array}{c}\text { menyombo } \\
\text { ngkan diri }\end{array}$ \\
\hline 25 & & Al-A'rāf & 206 & $\begin{array}{l}\text { merasa } \\
\text { enggan }\end{array}$ \\
\hline 26 & تَكَبِيْرًا & Al-Isrā’ & 111 & $\begin{array}{l}\text { Pengagung } \\
\text { an yang } \\
\text { sebesar- } \\
\text { besarnya. }\end{array}$ \\
\hline 27 & مُنَكَبِّرْ & $\begin{array}{c}\text { Al- } \\
\text { Mu'min }\end{array}$ & 27 & $\begin{array}{c}\text { orang yang } \\
\text { menyombo } \\
\text { ngkan diri }\end{array}$ \\
\hline 28 & 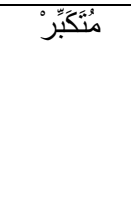 & Al-Hasyr & 23 & $\begin{array}{c}\text { Yang } \\
\text { Memiliki } \\
\text { segala } \\
\text { Keagunga } \\
n\end{array}$ \\
\hline 29 & المُنَكَبِّرَيْنَ & An-Nahl & 29 & $\begin{array}{c}\text { orang- } \\
\text { orang yang } \\
\text { menyombo } \\
\text { ngkan diri }\end{array}$ \\
\hline 30 & استخِكَبَارًا & Fāthir & 43 & $\begin{array}{c}\text { kesombong } \\
\text { an }\end{array}$ \\
\hline 31 & مُسنْتَبْبرًا & Luqmān & 7 & $\begin{array}{c}\text { menyombo } \\
\text { ngkan diri }\end{array}$ \\
\hline 32 & مُسْنَكَبِرُوْنَنَ & Al-Nahl & 22 & $\begin{array}{c}\text { orang- } \\
\text { orang yang } \\
\text { sombong }\end{array}$ \\
\hline 33 & مُسْنَكَبِريْنَ & $\begin{array}{c}\text { Al- } \\
\text { Mu’minū } \\
\mathrm{n}\end{array}$ & 67 & $\begin{array}{c}\text { Menyombo } \\
\text { ngkan diri }\end{array}$ \\
\hline 34 & كِيْر" & $\begin{array}{c}\text { Al- } \\
\text { Mu'min }\end{array}$ & 56 & $\begin{array}{c}\text { (keinginan } \\
\text { akan) }\end{array}$ \\
\hline
\end{tabular}




\begin{tabular}{|c|c|c|c|c|}
\hline & & & & kebesaran \\
\hline 35 & كَيْرَهُ & Al-Nūr & 11 & $\begin{array}{c}\text { Yang } \\
\text { terbesar }\end{array}$ \\
\hline 36 & الكِيَر & $\begin{array}{c}\text { Al- } \\
\text { Baqarah }\end{array}$ & 266 & Masa tua \\
\hline 37 & الكِبِرَ & Maryam & 8 & $\begin{array}{c}\text { Yang } \\
\text { sangat tua }\end{array}$ \\
\hline 38 & كَيْزِ & $\begin{array}{c}\text { Al- } \\
\text { Baqarah }\end{array}$ & 217 & Dosa besar \\
\hline 39 & كَيْرِ & Luqmān & 30 & $\begin{array}{l}\text { Maha } \\
\text { Besar }\end{array}$ \\
\hline 40 & كَيْرِ & $\begin{array}{c}\text { Al- } \\
\text { Qashash }\end{array}$ & 23 & $\begin{array}{c}\text { Orang } \\
\text { yang telah } \\
\text { lanjut } \\
\text { umurnya }\end{array}$ \\
\hline 41 & كَيِيرًا & $\begin{array}{c}\text { Al- } \\
\text { Baqarah }\end{array}$ & 282 & Besar \\
\hline 42 & كَيْزْ & Yūsuf & 78 & $\begin{array}{c}\text { Yang } \\
\text { sudah } \\
\text { lanjut } \\
\text { usianya }\end{array}$ \\
\hline 43 & كَيْيْر & Al-Isrā' & 43 & $\begin{array}{c}\text { Yang } \\
\text { sebesar- } \\
\text { besarnya }\end{array}$ \\
\hline 44 & لكَيْرُكم & Tāha & 71 & $\begin{array}{c}\text { Pemimpin } \\
m u\end{array}$ \\
\hline 45 & لكَيْيرُهم & Yūsuf & 80 & $\begin{array}{c}\text { Yang } \\
\text { tertua }\end{array}$ \\
\hline 46 & لكَيِْرُهم & $\begin{array}{c}\text { Al- } \\
\text { Anbiyā' }\end{array}$ & 63 & Yang besar \\
\hline 47 & كَبَرَاعَنَا & Al-Ahjāb & 67 & $\begin{array}{l}\text { Pembesar- } \\
\text { pembesar }\end{array}$ \\
\hline 48 & كَيْرَرَهُ & $\begin{array}{c}\text { Al- } \\
\text { Baqarah }\end{array}$ & 45 & Berat \\
\hline 49 & كَبَائرَ & Al-Nisā' & 31 & $\begin{array}{c}\text { Dosa-dosa } \\
\text { besar }\end{array}$ \\
\hline 50 & كَبَّارًا & Nūh & 22 & $\begin{array}{c}\text { Yang amat } \\
\text { besar }\end{array}$ \\
\hline 51 & أَكَبرَ & $\begin{array}{c}\text { Al- } \\
\text { Baqarah }\end{array}$ & 217 & $\begin{array}{l}\text { Lebih } \\
\text { besar }\end{array}$ \\
\hline 52 & أكَابرَ & $\begin{array}{c}\text { Al- } \\
\text { An'ām }\end{array}$ & 123 & $\begin{array}{c}\text { Yang } \\
\text { terbesar }\end{array}$ \\
\hline 53 & الكَبْرَى & Tāha & 23 & $\begin{array}{c}\text { Yang } \\
\text { sangat } \\
\text { besar }\end{array}$ \\
\hline 54 & الكَبْرَى & $\begin{array}{c}\text { Al- } \\
\text { Dukhān }\end{array}$ & 16 & Yang keras \\
\hline 55 & الكبَرَ & $\begin{array}{c}\text { Al- } \\
\text { Muddatst } \\
\text { sir } \\
\end{array}$ & 35 & $\begin{array}{c}\text { Yang amat } \\
\text { besar }\end{array}$ \\
\hline 56 & الكِبِرْيَاءُ & Yūnus & 78 & Kekuasaan \\
\hline 57 & الكِبْريَاءُ & $\begin{array}{c}\text { Al- } \\
\text { Jātsiyah }\end{array}$ & 37 & $\begin{array}{c}\text { Keagunga } \\
n\end{array}$ \\
\hline
\end{tabular}

Setelah diteliti dalam Alquran, ditemukan berbagai makna tentang kabura dan turunannya, mempunyai beberapa makna yaitu makna berat, besar, dewasa, lanjut usia, tua, kekuasaan, agung, kagum, angkuh sombong enggan, tinggi, pemimpin.

\section{Makna Relasional}

Sikap sombong atau angkuh (istakbara) berkaitan dengan fenomena kufur dalam struktur semantik. Dalam konteks pagan Arab kesombongan merupakan aspek penting dalam mempertahankan harga diri sebagai cita-cita tertinggi moral badui, ${ }^{7}$ yang dimanifestasikan dalam bentuk keberanian dalam memperoleh kemuliaan, $^{8}$ tetapi kesombongan dan keberanian dalam masyarakat badui identik dengan balas dendam yang membuta tanpa mengenal aturan. Dalam konteks Alquran, kesombongan merupakan indikasi seorag kafir yang meremehkan dan mendustakan Tuhan, ajaran, dan Rasul-Nya. Dengan pengamatan sekilas kesombongan merupakan lawan dari iman, sehingga mereka yang sombong akan menolak keimanan dan tidak percaya terhadap ayat-ayat Tuhan yang disebabkan oleh sikap sombong. Maka kata angkuh (istakbara) berkaitan erat dengan fenomena kekufuran. Hal ini diperjelas oleh ayat yang menunjukkan hubungan yang mendasar antara syirik, kufur dengan sikap sombong dengan konsekuensi ancaman yang sama-sama keras. Persamaan semantik kesombongan juga berdampingan dengan kebohongan terhadap Tuhan sebagai lawan dari taqwa, termasuk orang yang suka berdebat tentang ayat Allah tanpa argumentasi kecuali sebagai kesombongan belaka.

Untuk memperjelas indikasi sombong sebagai bagian yang integral dengan kufur, harus dilihat beberapa karakter yang terkait dengan kesombongan. Diantara karakter tersebut adalah perbuatan melampaui batas (bagha) sebagai akar kerusakan dan kekerasan (zulm). Akar melampaui batas ialah bersenang-senang (batira), meskipun Alquran tidak banyak memberi keterangan tentang

7 Thoshihiko Izutsu, Konsep-Konsep Etika Religius Dalam Qur'ān. Terj. Agus Fahri Husein dkk. (Yogyakarta: Tiara Wacana, 1993), 80.

Thoshihiko Izutsu, Konsep-Konsep Etika Religius Dalam Qur'ān.100. 
struktur semantiknya yang berkenaan dengan indikasi kufur, tetapi akibat dari sikap ini menunjukkan indikasi yang sama dari akibat kekufuran yaitu dibinasakan dari negeri kediaman. Salah satu sinonim dari kesombongan (istakbara) adalah 'ata yaitu kesombongan yang keterlaluan dengan sikap penuh kedurhakaan terhadap perintah Tuhan. Sinonim ini dari istakbara adalah tagha dengan bentuk nominal tughyan yaitu sikap yang menunjukkan kekufuran yang amat sangat, karena permusuhannya terhadap rasul dan orang-orang beriman dan kecintaannya terhadap kehidupan dunia sehingga tughyan terkdang dilawankan dengan taqwa. Dalam konteks ini, termasuk karakter orang yang terlalu percaya diri sehingga menganggap dirinya tidak butuh siapapun, dalam kapasitas sebagai makhluk sikap semacam ini termasuk dalam kategori sombong dengan memakai istilah istaghna. Kata ini terkadang disandingkan dengan sikap yang melampaui batas dan dilawankan dengan takwa. Imbas dari sikap sombong biasanya disertai keinginan untuk menguasai orang lain, dan cenderung pada penganiayaan dan kedurhakaan. Sikap kesombongan semacam ini disebut dengan jabbār yang disandingkan dengan kata mutakabbir sebagai penguat (ta'kid) atas kesombongan seseorang. Sifat tersebut sangat erat dengan karakter orang kafir, yang diindikasikan oleh Alquran dengan terkunci mati hatinya dan dilawankan dengan taqwa. Jadi jelas bahwa sikap kesombongan merupakan perwujudan lain dari kufur. ${ }^{9}$

Menurut ar-Raghib al-Ishfahani dalam kitabnya Mufradāt fî gharīb Alquran, alMutakabbir adalah kata yang diambil dari kata kerja تكبر (kata bendanya: Takabbur) memiliki dua kemungkinan makna, yaitu: ${ }^{10}$

\footnotetext{
${ }^{9}$ Mustofa Umar, Konsep Kufur Dalam Al-Qur'ān Dan Proyeksinya Terhadap Teks Hadits, dalam jurnal Al-Risalah Volume 12 Nomor 1 Mei 2012, 54-55.

${ }^{10}$ Abu Qāsim al-Husain bin Muhammad al-Ma'ruf al-Rāghib al-Ishfahāni, Mufradāt fĩ Gharỉb Al-Qur'ān, jilid 1. (Beirut : Mauqi’u Ya'sub), 420-423.
}

a. Yang memiliki tendensi makna positif. Secara hakikat asmā' al-h̆usnā al-Mutakabbir masuk pada kategori ini.

b. Yang memiliki makna negatif. Makna negatif ini ketika Alquran menuturkan dengan khitab فبئس مثوى المتكبرين. - مثن.

Ketika kata 'takabbur' diarahkan pada makna yang pertama (kepada Allah) maka berarti perbuatan yang terpuji. Dan jika diarahkan pada makna yang kedua maka berarti perbuatan yang tercela.

Menurut 'Ensiklopedia makna Alquran' kata al-Mutakabbir adalah puncak dalam hal kebesaran dan keagungan (al-mubālighu fíalkibriyā' wa al-'uzhmah). dan pengertian takabbur sendiri ialah tidak menghargai kebenaran dan tidak tunduk kepadanya, dan disertai dengan sikap merendahkan oranglain. Orang sombong memandang dirinya tidak patuh dan tidak tunduk kepada kebenaran atau disamakan dengan oranglain. Jika diterapkan kepada manusia, maka manusia yang bersifat demikian sangatlah tercela. Semua sifat-sifat Tuhan itu, walau sama namanya dengan sifat manusia, esensinya berbeda. Sifat Tuhan tak terbatas dan tak terhingga.Sedangkan kata مُسنَخبريْنَن : orang-orang yang sombong. Yakni perilaku yang ditampilkan oleh orang-orang yang mempunyai ciri-ciri, antara lain: pertama, mereka yang tidak beriman dengan negeri akhirat, dan mengingkari ke-Esaan Allah (QS. Al-Nahl [16]: 22); kedua, mereka yang enggan diajak meminta ampun, dan membuang muka (QS. Al-Munāfiqūn [63]: 5); dan ketiga, mereka yang berpaling dari Alquran, dan melontarkan kata-kata keji terhadapnya (QS. Al-Mu'minūn [23]: 66$67)^{11}$

\section{Weltanschuung}

Kata al-Mutakabbir ini di dalam Alquran selalu dikaitkan kepada dua subyek yaitu kepada Allah dan manusia, sebagaimana penjelasan berikut ini :

${ }^{11}$ M. Duha Abdul Jabbar dan N. Burhanudin, Ensiklopedia Makna Al-Qur'ān Shara AlfāzhalQur'ān.(Bandung: Fitrah Rabbani: 2012), 559. 


\section{a. Mutakabbirnya Allah}

Mutakabbir adalah salah satu Asmā' alHusnā, seperti yang telah disebutkan dalam firman-Nya Al-Ḥashr: 23. Makna dari mutakabbir disanapun mengandung arti kebesaran/ keagungan Allah.

Ibn Mandzur mendefinisikan lafal alMutakabbir adalah "Zat yang tidak tersentuh oleh kezaliman hamba-Nya, karena dia Maha Agung lagi Maha Besar". Kata kibriyā' jika disandingkan atau disandarkan kepada Allah berarti keagungan Allah SWT. Mutakabbir artinya Agung, bukan sombong. Huruf ta dalam kata mutakabbir menunjukkan "hanya satu-satunya" bukan ta yang mempunyai pengertian sombong, tidak memiliki sedikitpun tentang kesombongan. ${ }^{12}$

Jadi ketika manusia sombong, dia hanya berpura-pura sombong. Karena hanya Allah saja yang berhak memiliki sikap sombong. Karena sombongnya Allah adalah bagian dari kasih sayang-Nya.

\section{b. Takabburnya Manusia}

Menurut Imam al-Ghazali dalam kitab Ihyā' 'Ulumuddin menyebutkan tujuh nikmat yang menyebabkan seseorang menjadi sombong: ${ }^{13}$

1) Pengetahuan (ilmu). Alangkah cepatnya sifat sombong itu timbul dalam hati orang-orang yang merasa cukup pengetahuannya.

2) Amal dan ibadah. Ini bisa menimbulkan sombong dan karenanya menarik perhatian orang banyak, kalau dia kurang ikhlas.

3) Kebangsawanan, karena merasa dirinya turunan bangsawan, dia menjadi sombong dan memandang rendah kapada orang yang dianggapnya rakyat biasa.

4) Kecantikan rupa. Ini lebih banyak pada kaum wanita. Bukan saja membawanya kepada kesombongan, tetapi juga suka

12 Jamaluddîn Muhammad ibn Mukarram ibn Ali, Lisān al-Arābi ibn Mandzur, jilid 5. (Kairo: Dār Ma'arif) ,3807-3808.

${ }^{13}$ Dikutip dari buku Fakhruddin, Ensiklopedia AlQur'ān, Jilid II: M-Z. (Jakarta: Rineka Cipta, 1992), 395-396. mencela, merendahkan dan menyebut aib orang lain.

5) Harta dan kekayaan. Karena merasa diri serba cukup, dia menjadi sombong dan memandang rendah dan melecehkan orang lain, terutama orang-orang miskin.

6) Kekuatan dan kekuasaan. Seseorang bisa menjadi sombong karena di tangannya ada kekuatan dan kekuasaan, memandang rendah terhadap orang-orang yang lemah.

7) Banyak pengikut, teman sejawat, karib kerabat yang mempunyai kedudukan dan jabatan-jabatan penting.

Sifat takabbur merupakan penyakit yang bisa membinasakan amal kebaikan manusia. Orang yang berlaku takabbur atau sombong adalah orang yang sakit secara mental, yang sedang menderita kesakitan secara jiwa. Hal tersebut pada sisi Allah SWT adalah terkutuk dan sangat dimurkai.

Meskipun sifat sombong merupakan sifat yang jika dimiliki oleh manusia mengandung sifat yang tercela, tetapi ada ungkapan yang mengatakan bahwa sombong terhadap orang yang sombong adalah shadaqah. ${ }^{14}$

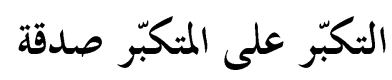

Ada juga hadits yang beda redaksi tetapi maknanya sama yang diriwayatkan dari Ibn Umar.

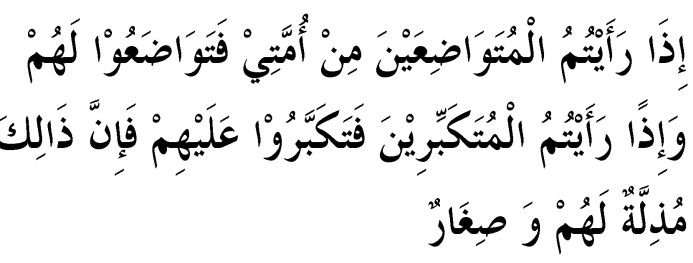

"Apabila kalian semua melihat orangorang yang bersikap tawadhu' dari umatku, maka bersikap tawadhu'lah kalian kepada mereka. Dan apabila kalian mendapati orang-orang yang menyombongkan diri, maka sombongkanlah diri kalian di hadapan

${ }^{14}$ Ini adalah ungkapan masyhur dari al-Razi, dan bukan hadits dari Rasulullah Saw. Lihat kitab Kasyfu al-Khafā' wa Majllu al-Albās 'Amma Istahara min alAhādits 'Alā Al-sinati al-Nās, jilid 1. Karya Ismail bin Muhammad al-'Ajalūnî dan kitab Asna Al-Mathālib Fî A hāāits Mukhtalipat Al-Marātib karya Muhammad bin Darwis bin Muhammad (Aplikasi Maktabah Syamilah) 
mereka, karena sesungguhnya yang demikian itu merupakan bentuk penghinaan, dan menganggap mereka kecil." (status riwayat hadits ini adalah ghārib).

Di dalam atsar para sahabat sepeninggal Rasulullah Saw disebutkan, bahwa Umar pernah berkata "sesungguhnya seorang hamba apabila ia bersikap tawadu' karena Allah, niscaya Allah pasti akan meninggikan (mengangkat) derajatnya dan memberinya hikmah atas perilakunya. Dan berkatalah malaikat yang menangani masalah hikmah itu, 'bangunlah dari jatuhmu, niscaya engkau telah diangkat oleh Allah.' Apabila hamba itu berbuat takabur serta melampaui batas, niscaya ia ditolak oleh Allah di muka bumi. Lalu, berkatalah malaikat yang menangani masalah hikmah, enyahlah engkau dari sini, niscaya Allah akan mengusirmu. Ia pada anggapannya, adalah orang besar. Akan tetapi, pada pandangan manusia hina. Sehingga ia sesungguhnya lebih hina daripada hewan pada sisi manusia. ${ }^{15,}$

Manusia boleh sombong dalam catatan untuk menunjukkan kepada orang yang sombong bahwa ada yang lebih dari dia, baik lebih kaya, lebih berkuasa, ataupun dari segi hal yang lainnya. Dan orang yang melakukannya juga ingat bahwa dia sombong untuk mengingatkan saja dan dia yakin bahwa yang lebih kuasa atau agung hanyalah Allah SWT. Seperti ketika menghadapi musuh dalam perang, manusia boleh berlaku sombong kepada lawan bahwa kita bisa menang dalam berperang. Supaya lawan tidak menganggap kita sebagai lawan yang lemah bagi mereka.

Meskipun begitu sikap takabbur memiliki banyak madharatnya dibanding dengan manfaatnya. Karena sedikit sikap takabbur ada dalam hati kita akan mengantarkan ke dalam neraka. Begitupula hadits yang diriwayatkan oleh Imam Muslim dari hadits Ibnu Mas'ud Rasulullah Saw bersabda

15 Al-Imam al-Ghazali, I $\underline{h} y \bar{a}$ ' 'Ulumudîn, Jilid 7. (Kairo: Dār al-Hadits). Terj. Ibnu Ibrahim Ba'adillah, (Jakarta: Republika), 21.

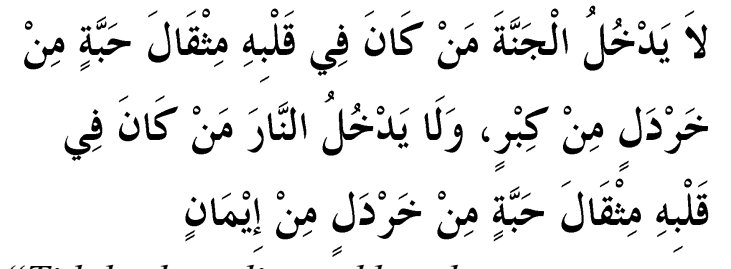

"Tidak akan dimasukkan ke surga orang yang di dalam kalbunya terdapat seberat biji sawi dari sikap takabbur. Sebagaimana tidak pula dimasukkan ke neraka orang yang di dalam kalbunya terdapat seberat biji sawi dari keimanan. "16

Rasulullah Saw juga pernah bersabda,

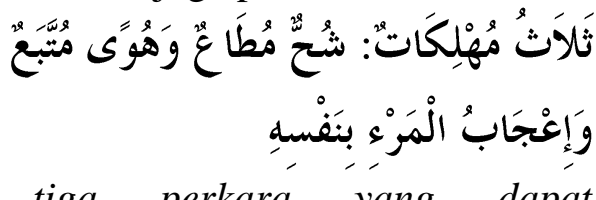

"Ada tiga perkara yang dapat membinasakan manusia, yaitu: sikap bakhil yang dipatuhi, hawa nafsu yang diikuti, dan kekaguman sseorang kepada diri sendiri" ${ }^{\prime 17}$

Keagungan dan keluhuran Allah SWT memecahkan punggung-punggung para Kisra (yang dimaksudkan adalah raja-raja Parsi). Keagungan dan kebesaran-Nya memendekkan tangan para Kaisar (yang dimaksudkan adalah raja-raja Romawi). Keagungan merupakan selimut bagi Allah. Sedangkan sikap takabbur menjadi selendang-Nya. Siapa saja yang melawan Allah pada kedua sifat tersebut, niscaya Dia akan memecahkannya dengan penyakit mati. Kemudian akan dilemahkan dari pengobatan atasnya. Mahaagung keagungan-Nya, dan Mahasuci nama-namaNya. ${ }^{18}$

\section{SIMPULAN}

Berdasarkan hasil penelitian tentang pendekatan semantik terhadap lafal alMutakabbir dalam Alquran maka dapat disimpulkan sebagai yaitu kata al-Mutakabbir

${ }^{16}$ Al-Imam al-Ghazali, Ihyyà' 'Ulumudin, 5.

17 Diriwayatkan oleh Imam al-Bazzar, Imam alThabrani, dan Imam al-Baihaqi dalam kitab asy-Syu'ab dari hadits Anas bin Malik ra, dengan sanad yang lemah (dhaif). Lihat kitab Al-Imam al-Ghazali, Ihy $\bar{a}^{\prime}$ 'Ulumudin, 4.

${ }^{18}$ Al-Imam al-Ghazali, Ihyā' 'Ulumudīn,4. 
mempunyai dua maksud : pertama, Yang memiliki tendensi makna positif yang menunjukkan makna terpuji. Kedua, kata alMutakabbir yang disandingkan kepada manusia memiliki makna negatif yang menunjukkan perbuatan yang tercela.

\section{DAFTAR PUSTAKA}

Hidayat, Ahmad. Teologi Qur'āni. Bandung: Gunung Djati Press, 1998.

al-Ghazali, Abu Hamid. Tauhidullah: Risalah Suci Hujjatul Islam. Cet. III. Surabaya: Tp, 2001.

Shihab, Quraish. Menyingkap Tabir Ilahi (Asmā' al-Husnā dalam perspektif alQur'ān). Jakarta: Lentera Hati, 2003.

J.P. Chaplin, Kamus Lengkap Psikologi, Terj. Kartini Kartono. Jakarta: PT Raja Grafindo Persada, 2011.

'Abdul Bāqī, Muhammad Fu'ad Al-Mu'jam Al-Mufahras Li Alfādz Al-Qur'ān AlKarim. Kairo: Dār Al-Hadith, 2007.

Izutsu, Thoshihiko. Konsep-Konsep Etika Religius Dalam Qur'ān. Terj. Agus Fahri
Husein dkk. Yogyakarta: Tiara Wacana, 1993.

Mustofa Umar, Konsep Kufur Dalam AlQur'ān Dan Proyeksinya Terhadap Teks Hadits, dalam jurnal Al-Risalah Volume 12 Nomor 1 Mei 2012.

Al-Ishfahāni, Abu Qāsim al-Husain bin Muhammad al-Ma'ruf al-Rāghib. Mufradāt fiGharīb Al-Qur'ān, jilid 1.Beirut: Mauqi'u Ya'sub,tt.

Abdul Jabbar, M. Duha dan N. Burhanudin, Ensiklopedia Makna Al-Qur'ān Shara Alfāzhal-Qur'ān.Bandung: $\quad$ Fitrah Rabbani: 2012.

Jamaluddin Muhammad ibn Mukarram ibn Ali, Lisān al-Arābi ibn Mandzur, jilid 5. Kairo: Dār Ma'arif, tt.

Fakhruddin, Ensiklopedia Al-Qur'ān, Jilid II: M-Z. Jakarta: Rineka Cipta, 1992.

al-'Ajalūnī, Ismail bin Muhammad. Asna AlMathālib Fì Ahādith Mukhtalipāt AlMarātib (Aplikasi Maktabah Syamilah). al-Ghazali, Ihyca', 'Ulumudin, Jilid 7. Kairo: Dār al-Hadits. Terj. Ibnu Ibrahim Ba'adillah. Jakarta: Republika, tt. 